Editorial

\title{
THINKING ABOUT CLASS, RACE, GENDER: HIMANI BANNERJI AND G.A. COHEN ON CAPITALISM AND SOCIALISM
}

\author{
ELAINE COBURN \\ Centre d'analyse et d'intervention sociologiques (CADIS)-Ecole des Hautes \\ Etudes en Sciences Sociales (EHESS) and American University of Paris. Paris, \\ France.
}

\author{
Key Words \\ class; G.A. Cohen; gender; Himani Bannerji; race \\ Mots-clés \\ classe; G.A. Cohen; genre; Himani Bannerji; race
}

Socialism is, at minimum, a twin enterprise. It is at once a critique of capitalism and an argument for moving beyond capitalism to a world in which social relationships are governed by the principle, "From each according to ability, to each according to need." Put another way, socialism is first a critical appraisal of the actually-existing political economy of capitalism and second, an argument for a particular kind of postcapitalist world. Among others, G.A. Cohen has argued that under scientific socialism as elaborated by Marx and Engels and perhaps more especially by Rosa Luxemburg - the two projects were united (Cohen 2001, 73-78; 100-115). The reason that the socialist critique of capitalism and the project for a socialist society were one and the same endeavour is that the socialist solution to capitalism was immanent in the historically unequal and exploitative class relationships that are at the heart of capitalism. Out of the successful revolutionary struggle of the majority working class against the dominance of the minority capitalist class would emerge an unprecedented moment, the beginning of human history. Rid of limiting reifications like "the economy" and "the market" and most importantly, of the unequal social relations underlying them, human beings would selfconsciously and democratically organize social relationships together. Democratic decision-making, in the best socialist variants, would no longer be confined to a narrow and artificially carved-out formally political realm but would also include the economic realm and other aspects of social life. This new socialist society would meet the particular needs of each human being, while sharing social burdens (Cohen 2008, 138), so enabling the fullest expression of human potential for each and all. 
For scientific socialists, there was, however, no need to argue for the socialist project, in the absolute, since it was an inevitable consequence of revolutionary class struggle emerging within capitalism. As Cohen observes (2001, 109), although Marx, Luxemburg and many less well known activists and authors made (and some continue to make) great personal sacrifices in the name of socialism, ostensibly these sacrifices were not over an uncertain future, but rather to speed along an inevitable, ultimately victorious revolutionary working class struggle (Cohen 1995, 3, 6). Yet, if it is a certainty that capitalism will not last forever, anymore than feudalism or other modes of production in human history, it is not obvious that socialism, and specifically democratic socialism, will inevitably succeed capitalism. Cohen argues that in particular, there is no world-wide immiserated working class with nothing to lose that will emerge to carry out the socialist revolution (for instance, Cohen 1995, 7-9) and no ecological possibility of the superabundance that will make equality unproblematically attainable, since many wants cannot be met under the ecologically-necessary conditions of reduced consumption. If Marx and others in his wake elaborated a very helpful explanation of capitalism and a trenchant critique of capitalist injustice (or of objective exploitation, as Marx would have it) and if socialism remains a compelling political project, socialism is no longer an inevitability but simply one possible -- and possibly unlikely -- political future among others.

\section{Social Location and Socialist Theory}

To explore the tension between the socialist critique of capitalism and socialism as a more just way of organizing social relationships, I look at the work of two scholars, sociologist Himani Bannerji ${ }^{1}$ and the late philosopher G.A. Cohen. G.A. Cohen's work is the focus of the articles and research notes in this special issue, drawing on a Socialist Studies conference organized in 2010 by libertarian philosopher Jan Narveson, who contributes a comment on Cohen's work and afterward to this issue.

Himani Bannerji and G.A. Cohen were born just one year apart, 1942 and 1941 respectively. Each spent many formative years in Canada and each was an immigrant, Bannerji coming to Canada from Bengal, India and Cohen leaving Canada for Britain as a doctoral student. Both experienced discrimination and prejudice on ethnic/racial grounds. Both explicitly characterize themselves as committed to socialist struggles, so that both operate at least partly on the margins of academia, where Marxism has been of

\footnotetext{
${ }^{1}$ Due to technical difficulties with the audio file, we regret we are unable to publish the interview of Bannerji conducted by Sherene Razack, herself a devastating critic of the interlocking systems of injustice that are capitalism, patriarchy and racism (see, for instance Razack 2008), originally planned for this issue. We hope to be able to publish it in the next volume in some form.
} 
declining significance over the last several decades -- if far from dead, as their own lively work, among others, attests.

Yet, despite these generational, biographical and political affinities, Cohen and Bannerji espouse quite different socialisms. I will suggest these have their roots in their respective social locations. As Bannerji would insist, biographical differences are not only about personality and talent, family and culture. Rather, more often than not, they are an expression of power, and of how power operates to include and to exclude. Indeed, they are even about how power operates to create certain socially meaningful and consequential categories of actors in the first place. In her own words, for example, Bannerji became a "woman of colour" within the settler state of Canada. And of course, "power" is never generic, but always occurs in historically-specific forms, for instance, as class relations.

In other words, biography is always-also about the personal experience of political power, the ways that, as Bannerji reminds us, "the political is personal," to invert the wellknown feminist slogan (Bannerji 2000, 88). In this way, the account that I offer of Bannerji and Cohen's intellectual biographies emphasizes the weight of history on the ways their respective socialist engagements developed.

\section{Himani Bannerji: Sociology from the Margins}

Himani Bannerji is Bengali-Canadian. Following tenured professorship in India, she was for a long time a precarious academic in Canada before finally becoming a tenured professor at York University, in the Department of Sociology. As noted, Bannerji emphasizes how, within the context of London, England and later in Canada, she became an immigrant, ethnic, a "visible minority" within a white supremacist nation conceptualized in terms of the two warring "solitudes" of the colonizers, English and French (Bannerji, 2000, 88). Within the patriarchal, imperialist capitalist configuration of the Canadian state, with its commonsensical racialization that interpellates people of colour as such $(2000,65)$, Bannerji became an implicitly inferior "other" against an universalized white male norm, whether the referent is the French or English-speaking colonizer.

Of course, Bannerji's personal entwinement in colonial relations did not begin with her arrival in Britain and Canada. Already in India, she had been enrolled in a school where English was the language of instruction and Shakespeare the centre of a wholly British canon, taught to Bengalis in a self-conscious effort to create an English-speaking Bengali elite thoroughly tied into the colonial imaginary (Bannerji 1995, 55-56). It was, however, as an immigrant, that Bannerji first felt the full force of the painful and dehumanizing process of becoming an inferior other - and this across all spheres of life, including academia and in the realm of feminist politics. 
Taking English literature classes at the University of Toronto, for instance, Bannerji felt her presence in and contributions to the class were, at best, irrelevant to the professor and other students, at worst, an intrusion on the 'normal' convivial course of class discussion (Bannerji 1995, 57-58). Her life experiences were made to seem completely irrelevant to and were entirely absent from course materials, and her person was made thoroughly alien through numerous small remarks, as with eminent professors who asked if she felt cold wearing a sari in the Canadian winters. Indeed, she felt so thoroughly alienated that she discontinued her $\mathrm{PhD}$ studies and only took up her university career again many years later. This time, thanks to writers like Frantz Fanon, Audre Lorde and Dorothy E. Smith, she was armed with the beginning of a reflexive, critical awareness of the political structures underpinning her feelings of isolation as an immigrant woman of colour (Bannerji 1995, 60).

In her re-started academic career, Bannerji sought to become, not simply an "object" produced by the relations of ruling, but a political subject. She set herself the task of writing and teaching in order to lay bare and resist relations of domination, so laying the path for a new, feminist, anti-racist socialist world $(1995,106)$, rooted in what Bannerji calls "an actively revolutionary knowledge" $(1995,81)$. Inevitably, as one of the first non-white woman academics in Canada, this was a lonely business. Bannerji's allies were less often flesh and blood partners and more often texts written by far-flung black, Indigenous and other nonwhite women engaged in a similar political and theoretical struggle. Moreover, being armed with a reflexive awareness of the practical ways that oppression operates within academia, did not make the experience of oppression any less painful in everyday practice. Bannerji writes that within the classroom, she was constantly reminded that she was an exception to the university rule: "As a body type I am meant for another kind of work-but nonetheless I am in the classroom", exercising a kind of authority as a professor (Bannerji 1995, 61). Both as a consequence and symptom of this, she has had to continually establish her status as an equal before her students and to colleagues, an often exhausting business. At times, white students and colleagues, including those explicitly committed to feminist and historical materialist approaches, sought to empathize or express white guilt. Apart from the very rare exception of feminist scholar Dorothy E. Smith, however, her colleagues were not prepared to engage in systematic analyses of the ways their own teaching, research and collegial relationships are implicated in racist and patriarchal relationships (Bannerji 1995, 111).

More often than not, the public, professional academic experience of teaching and research was painful, even enraging. But within the classroom, pain and rage could not be directly expressed. Instead, Bannerji coped by splitting her "professional" self from her personal self. The personal self submitted to the violent gaze of mostly white students and colleagues, a gaze simultaneously reflecting and enacting "centuries of 'knowing' of existential and historical racism" (Bannerji 1995, 102). The professional self transformed that experience into analysis, one that stretched from the classroom to the history of the 
world. Thus, Bannerji teaches and writes in order to make clear the connections between, for instance, the social violence of the classroom gaze she experienced and the racist ideologies of colonizers who need(ed) to justify the violent takeover of "brown" peoples and their lands, so that these could be reorganized within colonial class relationships (1995, 99-120).

Within academia, Bannerji's marginality was accentuated by her Marxism. It is not difficult to imagine how her officially precarious university status, throughout much of her career, could be justified by so-called objective standards of academic excellence. Thus, publication in mainstream journals, using mainstream theories less disturbing to existing power relationships than Marxism is necessary for scholarly advancement (Smith 2004, 37-44). Moreover, it is telling that Bannerji feels compelled to specify her own antiracist and feminist orientation within mainstream Marxism. Like most academic theories, mainstream Marxism remains premised on the wholly unjustified assumption that it is possible to talk about actually-existing social relationships in capitalism whilst abstracting from -- that is, ignoring --the simultaneously racialized and gendered but also ableist and heterosexist nature of social life. As if, writes Bannerji, "nothing much is to be learned about the nature of economic, social and political organization...by studying lives or concerns of women of colour" $(1995,43)$. By insisting on the centrality of the simultaneous experiences of race, gender and class oppressions within the historically specific configuration of world capitalism, Bannerji seeks to challenge a canon that institutionalizes these as "objectively" minor dynamics - but the immediate price is to be dismissed as a scholar concerned with "minor" issues.

This status as inferior outsider was and is not confined to academia. Mainstream feminist politics, Bannerji writes, ironically sought to silence women of colour and working class women, all while insisting on giving "women" a public voice (1995, 41-54). And, there was and is the everyday racism. Riding with her daughter on the subway in Toronto, for instance, fellow passengers watched as she struggled to free her child from being jammed in the doors, all the while making comments about "you people" not knowing how to properly ride the metro system $(1995,13)$. In short, Bannerji's early, precarious existence within academia and Canada cannot be separated from her social existence as a non-white woman in a white settler nation.

Yet, if objectively caught in relations of domination and oppression, Bannerji is not simply a victim of those relations. As she writes about herself, "I am object, but also subject" $(1995,104)$. Bannerji did find both literary and flesh and blood allies in academia and beyond, in her struggles, and she has continued to engage in projects of pedagogical but also political resistance. Moreover, if her work is firmly committed to critique, it is likewise insistent about the possibility and necessity of revolutionary, emancipatory social transformation. Finally, Bannerji is a poet, too. Like her sociology, her poetry - what might be referred to as "resistance poetry" (Armstrong 2001, xvii)-- speaks both of the violence of many contemporary social relationships and of the possibility of transcending 
that violence: she writes of broken birds who are, nonetheless, also phoenixes rising (Alvarez 2007, 18).

\section{G.A.Cohen: Success at the Centre}

G.A. Cohen's childhood was spent in working-class Jewish Montreal. He grew up in a Russian émigré family committed to communism. Like Bannerji, Cohen experienced ethnic hatred as well as the sometimes frightening marginality and even criminalization associated with active socialist politics. The left-wing and bilingual Yiddish-English primary school he attended was closed following a raid by Quebec's 'Anti-Red' brigade (Cohen 2001, 27-30). Following this, Cohen assiduously hid his communist convictions from his classmates until his teenage years, when he was accidentally politically 'outed' and realized to some surprise that being identified as communist had a certain cachet among his adolescent friends. Whatever the rebellious allure this affiliation gave him in the eyes of his classmates, however, Cohen remained all-too aware of the brutality of anticommunist activities by the Quebec police and he writes of the fear he felt as a child and young adolescent when carrying out semi-legal errands for his communist parents and their friends.

Following the closure of his primary school, Cohen attended English protestant schools, partly in order to avoid the more explicit anti-Semitism at the French Catholic ones. Inevitably, this left him exposed to what he refers to as 'genteel' Protestant antiSemitism (Cohen 2001, 28). As a Jewish child growing up in Montreal, this included formal discrimination, including signs at public and private establishments forbidding entry to Jews and discriminatory entrance requirements at McGill University that meant Jewish students had to outperform Christians in order to be accepted. It also meant exposure - and the everpresent fear of exposure -- to other forms of everyday, informal anti-Semitism, including insults shouted out in the streets and barbs aimed at Jewish students by their teachers. As Cohen remarks, it only took the very occasional antiSemitic slur yelled out in the street to instil a long-lasting feeling of vulnerability (2001, $34)$.

Cohen writes that these experiences of discrimination enhanced his own sense of Jewishness, as well as feelings of vulnerability, exclusion and even self-loathing (2001, 3437). Remembering a male teacher who revelled in anti-Semitic asides in the classroom, for instance, Cohen describes the destructive ways that deference to the authority represented by such a teacher meant that, "you have a kind of deference to his views that Jews are not quite human, or that they have all too many of the less agreeable human characteristics, and that doesn't help you to respect yourself" (Cohen 2001, 37). In the same book, he insists on "how damaging racism is to the self-respect of its victims" (188). The "big wide 
non-communist world", (Cohen, 1995, 247) as Cohen refers to it, was not necessarily a friendly and too often a hostile, place.

In spite of the ambient, often vicious anti-communism and anti-Semitism of his Montreal youth, Cohen succeeded in undergraduate studies at McGill University. Cohen offers this assessment of his survival of anti-Semitism in his youth: "I experienced antiSemitic attitudes as a Jewish child in Montréal, but the consequences of that for us were not very severe, since, unlike many other victims of racism, we Jews had assets (not least ones of culturally induced self-confidence) that made the ambient anti-Semitism relatively ineffectual with respect to our life chances" (Cohen 2008, 367). Cohen went on to complete his doctoral studies at Oxford; he had also been accepted into the doctoral programme at Harvard, but declined. Subsequently, he became faculty at University College, London, where he worked for twenty-two years, before becoming Chichele Professor of Social and Political Theory, in 1985, so returning to Oxford at All Souls College. In short, by mainstream definitions, G.A. Cohen had a very successful university career, firmly at the academic centre of an old imperial power.

Nonetheless, success was not unmarked by continuing experiences of discrimination and marginality. Michael Rosen, for example, writes that eyebrows were raised to see a Marxist at All Souls (Rosen 2010, 13). In his writing, Cohen is forthright about the anti-Semitism of contemporary Britain $(2001,38)$, although he suggests that in his early academic career in Britain anti-Semitism was so muted that he could not identify with British Jews, who were simultaneously more religious and more assimilated than he felt. (Nor were they Yiddish speaking Russian émigrés, which was Cohen's own Jewish inheritance). Although Cohen does not talk about the experience of being an academic with working class roots, it is not implausible - if far from certain --that this created some sense of dissonance and ambivalent sense of belonging. Cohen was well-known for his informality and lack of inhibitions: who knows how this irreverence might be connected to his working class origins and experiences of anti-Semitic discrimination and exclusion?

Finally, Cohen may also have suffered from material disadvantages, relative to other academics, as a consequence of his socialist orientation. Just over a decade ago, when he was already well-known, Cohen remarked that if, like most professors, he was relatively rich, he was also 'quite poor, as professors go' (Cohen 2001, 150, italics in original). Cohen is not forthcoming about why, writing about "various reasons that need not be laid out here" (150). Nonetheless, in the contemporary capitalist world and particularly given restraints on public funding of universities, professors of philosophy are likely to be less well remunerated compared to professors in - for instance - relatively better-endowed business departments, who are oriented to the practical workings of everyday market societies. Generally speaking, socialist philosophers are less well known and in demand compared with liberal superstars like Rawls, who owe their renown and enthusiastic acceptance partly to the fact that they espouse theories congenial to existing capitalist power relationships. Despite important networks of solidarity amongst many 
left scholars, socialist professors' ideological marginalization has disadvantageous material consequences, relative professors with more acceptable political leanings.

Yet, it seems clear that G.A. Cohen did not only benefit from Jewish solidarity, as he mentions above, in carving out his academic career. Rather, within contemporary capitalism, maleness and "whiteness" are nonproblematic -- or "transparent" to borrow Frantz Fanon's term. Bannerji became a visible minority within the context of the imagined multicultural community of England and Canada, including within academia. In contrast, Cohen appears to have been more easily absorbed into mainstream academia in Oxford, England, despite his committed socialism and Jewishness. To paraphrase Bannerji, as a body type, Cohen's white maleness is meant for the kind of work done in a university classroom -- particularly, it might be argued, in an Oxford classroom. As a consequence, Cohen's status as a professor did not need to be constantly and repeatedly achieved, but was to a large extent already-acquired. The flip side of Bannerji's exclusion and marginalization within academia as a racialized woman of colour is Cohen's lessdifficult inclusion as a white man, possessing the automatic - and professorial -authority that a particular (white, male) body represents. ${ }^{2}$

Both Bannerji, the sociologist, and G.A. Cohen, the philosopher, make important contributions to socialism as a critique of capitalism and socialism as a more just way of organizing social life. Not surprisingly, however, given their distinct social locations, Himani Bannerji and G.A. develop different socialist critiques of capitalism and arguments for a socialist future, as a more just way of organizing human relationships. Their approaches are not always complementary. Moreover, there are uneven dangers in their respective contributions to the socialist critique and the socialist social project.

\section{Himani Bannerji and the Sociology of Socialism}

To twist a phrase of Cohen's, Bannerji has been concerned with the "hard factual carapace" (Cohen 1995, 6) of capitalist social relationships as they are lived, both historically and in a variety of national settings, including India, Canada and elsewhere. Bannerji insists that any clear-eyed assessment of actually-existing capitalist relations must recognize the ways that race, gender and class oppressions are inextricably meshed together in social experience. "Race, gender and class" are too often recited in this way: in serial but also rote fashion, with the artificial separation marked by the commas between

\footnotetext{
${ }^{2}$ This maleness and perceived whiteness is not a "privilege" that Cohen could simply and single-handedly renounce. It is not as if gender and race is a matter of personal choice. Rather, they are a consequence of social relationships - that of course, Cohen also participated in - that render some individuals, like Cohen, male and white in the same movement that others become women and "minorities", while simultaneously positioning men and whites as superior and femaleness and "otherness" as inferior. Of course, if Cohen could not renounce white privilege, he could analyse and critique racist relations - and he sometimes did (for instance, Cohen 2008, 345-50), within his more general argument for socialist justice.
} 
each word. In fact, the experience of race, gender and class are always "all together" and "all at once" (Bannerji 2005, 144). A human being is not first, a woman, then, a person of colour, and third, working class. Rather, she is always all-at-once: race, gender and class are inseparable as "coffee and milk" once they have been mixed up together (Bannerji 2005, 149). As Bannerji observes, the women who mistook her for the cleaning woman of a building she was in, had no trouble simultaneously thinking about race, gender and class (Bannerji 1995, 12). Theory cannot do less, if it does not want to engage in a misleading fragmentation of actual experience. The problem is at once conceptual and political: conceptual since it reifies as separate objective "fragments" what are unified social experiences (Bannerji 2005: 146) and political since this fragmentation is then reproduced in strong distinctions between communities and movements, that then have difficulty accomplishing unified political action.

Bannerji often starts from experience, including her own, to explore actuallyexisting relations under capitalism. This approach is based on the observation, already cited earlier, that the "political is personal". Inevitably, we are enmeshed in the politics the political economy -- of the world, which is nothing more than relations among human beings. But, there is nothing transparent about experience (Bannerji 1995, 55-98). Rather, processes of domination and exclusion are normally hidden through the commonsense sense of everyday ideologies that rewrite these relationships of oppression as natural, inevitable even desirable for most people. Experience must be interpreted -and interpreting in counterhegemonic ways is anything but spontaneous. Bannerji was not born an anti-racist feminist socialist, but become one. Similarly, it was only after encountering the writings of Fanon, Lorde, Smith and others that Bannerji was able to "see" many years later that her feelings of loneliness and irrelevance as a university student were a product of racism (Bannerji 1995, 56). Racism here is interpreted materially - as a pragmatic, social fact, existing in everyday, often institutionalized relationships that, for instance, define what "matters" within the classroom as the history and stories of white, European bourgeois people. In such a reading, personal experience is analytically explainable only within the understanding of a worldwide context of the historically specific configuration of capitalist imperialism that brings people together in definite, unequal class relationships, a configuration that is legitimated by ideas that racialize both whites and brown people, whilst positing whites as superior to others.

Bannerji observes that hegemonic ideas are not uniform and homogenous. On the contrary, they are frequently contradictory, because they shift pragmatically to fit with the interests of dominant classes in particular historical moments and situations (Bannerji $2001,48)$. For instance, in the colonial imaginary of the past and present, brown men are variously construed as authoritarian, barbaric, violent and effete. Brown women are then seen as requiring rescue from enlightened white Europeans, although this stereotype of brown women as victims is not stable either. Yet, Bannerji insists, in investigating ideas, it is not enough to examine the specific, practical and contradictory content of hegemonic 
ideas, although of course this is vital. (Too often, Bannerji argues, this description of ideological content is where postmodern theorists, with their emphasis on the discursive and the intertextual, stop). Rather, it is necessary to understand the epistemology behind the ideological content, the methods through which knowledge is produced (Bannerji 2001, 20-31). Ideas and culture are always-also social, that is, created in distinct, material relationships and conditions; the "knower" does not exist outside of the social relationships studied, but instead is located within them.

In her book Inventing Subjects (2001), for instance, Bannerji explores how "India" is produced as an object of knowledge within specific circumstances. William Jones, author of a once-authoritative text of India, was at the time of writing, the head of the colonial justice system. His aim, as administrator, was to seek to create "a just and benevolent rule over India in keeping with its own nature" $(2001,35)$, in Bannerji's words. Thus, Jones' India is a fixed, ancient society which has, however, been corrupted by weak, submissive but potentially powerfully deceptive "native" actors, including deliberately unreliable translators. (Hence Jones's insistence on the importance of learning local languages, to better survey potentially subversive native go-betweens (Bannerji 2001, 41). The role of the British rulers, in the justice system in particular, is then justified as the "restoration" of authentic ancient law to India, as written up in centuries-old scripts, against the dissembling natives (Bannerji 2001, 40-41; 48). British colonial rule, resistance by the colonized and the colonial relationship itself disappear in Jones account (Bannerji 2001, 36) . Instead the dominant story - underwritten by Jones own "authoritative" social and cultural history of India -- is that of the problem of applying authentic Indian law to Indians. As this example suggests, ideas have content, which matters. Here, for instance, is the more or less familiar trope of an ancient civilization that has been degraded by its own inhabitants and now requires rescue from civilized interpreters, who are in fact colonizers. But that content is only explainable via thorough examination of how and why ideas are produced (Bannerji 2001, 28), in this case, as expert knowledge, by and ultimately for the colonizers --but in the name of the wellbeing on the colonized.

Shifting her critical gaze to Canada, Bannerji demolishes the argument that official "multicultural" policy in Canada represents a liberatory or progressive programme. In her book, Dark Side of the Nation (2000), Bannerji unmasks multiculturalism as an ideology premised on the English or French colonial state paternalistically "granting" recognition to racialized others defined as if they are segmented and internally culturally homogenous communities. At best, the state positions itself in a "patron-client" relationship, with rewards granted on the basis of state-evaluated "good conduct" (Bannerji 2000, 116). At the same time, this emphasis on static, robust cultures means that the problems caused by racist, exclusionary practices may be attributed to inadequate, pathological, even criminal "cultures" among "minorities". In this way, the oppressed become responsible for their own domination: 
when young black men are shot by police, the explanation is that young black men are violent, the consequence of growing up in an impoverished, inferior culture (Bannerji 2000, 116).

In fact, however, multiculturalism is not primarily about its ostensible object, culture. Rather, multiculturalism is about the construction of shared "community" identities based on bodies and skin colour. In this way, it is multiculturalism that creates "visible minorities" (Bannerji 2000, 31; 104; 11-112; 116). Brown bodies become visible in contrast to normative hence "invisible" white ones. At the same time, nonwhites are labelled minorities because then their demands, in any case restricted to very limited power sharing, can be legitimately ignored in favour of what is implicitly redefined as "majority" white politics, whatever the actual numbers. In practice, an important function of official multiculturalism is to write out the possibilities for genuine politics. Questions of power, of racism, of workers' rights, of family reunification for migrant workers (Bannerji 2000, 44), are all erased in a unique focus that is supposedly "culture" but that is, in fact, about reifying racialized communities. This characterization of important swathes of the Canadian population, including migrant workers and others, undermines possibilities for political action based on the "genuine contradictions in our society" (Bannerji 2000, 120). The horizontal potential for struggles based upon the reality of unequal social relations - struggles against racism, against violence against women, against poverty, against heterosexism (Bannerji 2000, 119)-- is lost in the official "recognition" of supposedly internally homogenous, but separate and fragmented, ethnic communities.

As Bannerji insists, however, her critique of historically specific kinds of oppression that are an everyday part of actually-existing capitalist relationships is not the end point of her work (1995, 83-89). Rather, she is interested in a detailed description and explanation of how relations of inequality work and why they take the historically specific forms they do, in order to better consider how they may be subject to revolutionary transformation. Analyses matter, Bannerji argues, because they imply different politics of resistance for social actors who are never simply victims of the relations of domination in which they act, but also potentially revolutionary actors. In particular, Bannerji points out that the failure to conceptualize race, gender and class inclusively comes at significant political cost to socialist movements, who lose support from much of the working class when race and gender are dismissed as irrelevant or as "distracting" from class issues (Bannerji 2005, 147). Symmetrical problems exist for movements of racial justice that ignore class as a "white" issue or among women who argue that the fact of being a woman is of primordial significance "over and above" considerations of class and race. Capitalist injustice succeeds in part because it has successfully fragmented what is, in fact, the unified social experience of class-gender-race (Bannerji 2005, 155-157). Socialist justice will only succeed insofar as it based on recognition that class-gender-and-racial justice, can only advance altogether and all at once. 
Ultimately, for Bannerji, the critique of capitalist social relations throws into relief the urgency of creating radically new ways of living. The political goal is new social relationships, ones that allow human beings to freely and joyfully re-create themselves and the world around them (Bannerji 2001, 203). Underpinning this is what Bannerji refers to as an "ethical" commitment, a universal humanist affirmation that begins with an understanding of herself as a being in the world and "presuming the same for others" (Bannerji 1995, 13). In a world that assumes only white men's messages are of universal relevance, it bears repeating that Bannerji's socialist aspiration is not for a particular segment of humanity. She does not write exclusively for nonwhite women. Instead, her socialist aspiration is a universal one, for revolutionary transformation towards a more just social world for all. Fanon, too, emphasized his own history and identity as a 'nègre' while simultaneously affirming: "Je me sens une âme aussi vaste que le monde" -- I feel in myself a soul as immense as the world (Fanon 2011, 176). Bannerji claims no less.

\section{G.A. Cohen and the Moral Philosophy of Socialism}

G.A. Cohen, an analytical philosopher, offered a life-long defence of socialism, although the kind of socialism he defended changed over the years, as did the way he went about defending it. The book that made Cohen's name was Karl Marx's Theory of History: A Defence (2000), a collection of essays that takes the central arguments set forth by Marx and examines them, piece by piece, taking care, as Cohen explains, to be precise of statement and rigorous in argument (Cohen 2000, xviii). Against looser and more romantic representations of Marxism - what Cohen sometimes memorably referred to as "bullshit Marxism" -- analytical philosophers are bound, Cohen writes, to ask themselves: "precisely what does this sentence contribute to the developing exposition or argument, and is it true?" (Cohen 2000, xxii, italics in original). In this way, Cohen sought to subject Marxism to the "rule of reason" (Cohen 2000, xxiv). His "defence", which includes a thoroughgoing scrutiny of all major Marxist concepts, from class to the means of production to fetishism to the relationship between base and superstructure, ultimately led Cohen to reject some key Marxist arguments. Notably, this included the rejection of determinist theses about the inevitability of socialism. As I noted in the introduction, the inevitability thesis depends in Cohen's view upon untenable arguments about the emergence of a large, world-wide, impoverished working class with nothing to lose and on the equally untenable prospect of material abundance without natural, ecological limits.

What was left of his Marxist commitment, Cohen argued, was "the foci and preoccupations, the aspirations and values, of traditional Marxism" (Cohen 2000, xxiv). In particular, Cohen argued that the main questions that remain to inspire contemporary historical materialists, to paraphrase a summary of his own work by Tom Mayer, are: 
What do we, as socialists, want? Why do we want it, especially as contrasted with capitalism? And finally, how can we achieve it, given the improbability of a working classled socialist revolution? (Cohen 2000, xxv). Arguably, Cohen's entire career was spent seeking to answer these questions.

By his later years, Cohen had entirely shed his commitment to historical materialism, insofar as this can be interpreted as requiring the development of "bold explanatory theses about history in general and capitalism in particular" (Cohen 1995,6). Increasingly, Cohen's writing was devoted to what he characterized as a typical normative political philosophical endeavour: the search for "timeless truths" and specifically for ultimate, "fact-insensitive" principles of socialist justice. Cohen justified this normative turn on the grounds that since socialist revolution is not inevitable, the only way to bring about a more just socialist world is through rigorously argued moral appeals. Specifically, Cohen maintains that bringing about socialism demands widespread acceptance of egalitarian commitments based on a new "ethos", which he describes as a "structure of responses" informing individual motivations (Cohen, 2001, 128). The socialist ethos is rooted in (the realizable possibility of) a sense of shared community or fraternity among people who see each other in non-instrumental terms, as fellows to whom they must justify their own way of living (Cohen 2008,15). For Cohen, socialism is a normative political project, informed by the rigorous establishment of coherent arguments on the basis of key principles - notably a commitment to egalitarianism -- that direct human responses within social life conceived as community.

In defence of socialism, both as a desirable way of organizing social life and as a feasible political possibility (Cohen 2009), Cohen attacked some of the stoutest defenders of the principles underlying capitalism or said to underlie capitalism. In Self-ownership, Freedom and Equality (1995), for instance, he wrote against the libertarian Nozick. There, he suggested that a better name for libertarians of Nozick's ilk would be "entitlement theorist" (Cohen 1995, 72), since their concern is less with freedoms than with rights to property: after all, the rights of property owners frequently decrease the freedom of nonowners, but this is not what exercises libertarians like Nozick (Cohen 1995, 60). Cohen argues that among entitlement theorists, Nozick, at least, makes patently false claims about things coming into the world with entitlements already attached to them so conveniently forgetting not only the continuing existence of unowned commons, like the air and pavement, but also the historical fact that at a particular moment things privately unowned became privately owned (Cohen 1995, 73). And, Cohen goes into considerable detail to refute Nozick on this point, among others, arguing that there is no conceivable, legitimate way that "full liberal private property" could be formed, that is not simply theft and that does not leave others worse off than if the acquisition had been left privately unowned (Cohen 1995, 77-78).

Typically for Cohen, this argument against a libertarian defence of private property ownership becomes the occasion for revisiting and refining "traditional" 
socialist claims. In this instance, Cohen argues that Marxists sometimes sound like entitlement theorists, when they argue that one of the reasons that workers' justly revolt against the capitalist system is because their labour entitles them to the products of their labour - and yet, part of this labour is appropriated, stolen, by capitalists as profit. Cohen observes that this Marxist entitlement proposition, grounded in the labour theory of value, is not compatible with another Marxist value: distribution to each according to needs (Cohen 1995, 153). He concludes that socialists better let go of the idea of entitlement to the product of one's own labour, if they are truly committed to the contradictory piece of socialism that is most worth holding onto: organizing social life so that each receives what is necessary to lead a decent, fulfilled life and shares social burdens.

In subsequent books (see, for instance, Cohen 2008), Cohen tackled the liberal philosophy elaborated by Rawls, in particular, his well-known "difference" principle. According to this principle, inequalities are just insofar as they are necessary to improve the lot of the least-well off. But, this Rawlsian principle suffers from a number of failings, considered both in itself and within the broader framework of justice that Rawls erects around this principle. For instance, Cohen argues that Rawls has an untenable vision of the just society, based on conformity to just coercive "basic structures" particularly the law (Cohen 200!, 132-140). This Rawlsian vision, Cohen maintains, artificially separates out "basic structures" like law from other formally "noncoercive" structures, like the family, that - in fact -- critically shape life chances. It doesn't make sense, Cohen argues, to maintain that a law is unjust because it is entrenches male dominance, while ignoring the ways that patriarchal attitudes practically entrench gender inequalities within families, in everything from housework to the education of children (Cohen 2008, 137). As Cohen puts its, "To the extent that we care about coercive structure because it is fateful with regard to benefits and burdens, we must care equally about the ethos that sustains gender inequality and inegalitarian incentives" (Cohen 2008, 138).

For a society to be just, Cohen argues, there must be much broader considerations than those allowed by Rawls in his exclusive focus on coercive "basic structures". For Cohen, social justice must prevail in at least four distinct realms. These are (1) the basic formally coercive structures, like law, which use preventative barriers and deterrent penalties to prevent certain behaviours (Cohen 2008, 144); (2) other formally "noncoercive" structures, like the family, where sanctions typically take on forms like criticism, disapproval, ostracism, and even in extreme cases, violence; (3) the prevailing social "ethos", understood a "set of sentiments and attitudes" that informs normal practices (Cohen 2008, 144); and (4) individual choice, where it is recognized that individuals do exercise choice but within contexts of heavy social conditioning and potentially high costs for deviating from dominant practices (Cohen 2008 141; 144). Only when justice prevails across all four of these domains, Cohen argues, can a society be said 
to be just. Yet, in terms of their importance for revolutionary social change, not all of these domains are equal.

Across his later work, Cohen maintains that it is change in the social ethos that informs broad social transformation. For instance, Cohen suggests, an early ecologist may seem like a social freak and the ecological practices she carries out may seem especially burdensome. But, as ecological consciousness spreads, the ecologist increasingly appears to be quite ordinary, the practices of reducing consumption, recycling and similar activities become "normal" and the sense of burden associated with carrying them out decreases (Cohen 2008, 142). The ecological social "ethos" becomes the new norm, radically changing everyday social practices and relations as a consequence, which then reinforce the ecological ethos. Of course, it is this conviction about the importance of social ethos to transformative social change that motivates much of Cohen's work, although in his later writings Cohen stresses that he is also interested in justice "as such", for him a separate matter from the actual practice of (socialist) justice (Cohen 2008, 306307).

In his accessible short essay Why Not Socialism? (2009), for instance, Cohen seeks to make the content of the socialist ethos explicit, explain why it is desirable and convince readers of its feasibility. He begins with his often-used example of the camping trip. Of course, as Cohen acknowledges, camping trips -- which Cohen himself did not especially favour as a pastime (Cohen 2009, 10)-- have some special characteristics. They are typically made up of small, mostly self-selected groups, where there is relatively easy mutual surveillance. Nonetheless, the camping trip is suggestive, insofar as it represents a common experience during which socialist values of community and egalitarianism seem "natural" and naturally desirable. At the same time, during a camping trip, market values and practices look strange and even reprehensible: few would countenance one camper eating all the fish, just because she owned the fishing rod. In short, the camping trip makes socialist values look less exotic and more feasible, all while highlighting the ways that normal capitalist values may come to seem, at best, morally suspect as a way of organizing social relationships. Through reasoned argument and examples like this one, Cohen seeks to convince readers of the reasonableness and desirability of socialist values of "community and (egalitarian) justice" (Cohen 2009, 80, my insertion). Why not socialism in all aspects of social life, including the economic realm currently governed by an acquisitive, inegalitarian ethos?

In this view, individuals have a critical responsibility that they arguably did not under Marx' historical materialism, with its inevitable unfolding of history. Indeed, Cohen writes quite early on that "behaviours of individuals are always where the action is, in the final analysis" (Cohen 2000, xxiv). But, this does not mean that socialism is a politics that happens only in the minds of individuals or even in the minds of many individuals living together in communities. It is not enough to have isolated individuals no matter how numerous -- convinced of the rightness and possibility of achieving 
socialist values. Rather, to be successful against a capitalist system that is largely "selfsustaining" socialists require "the power of organized politics" (Cohen 2009, 81). Socialism will only ever come about through the collective struggle of human beings. These are not, however, Marx' historical actors: they are not necessarily working class and even if they are, they are not only engaged in an "objective" effort to improve the lot of their class and reduce the suffering attendant to capitalist inequalities. Rather, they are motivated by community-oriented and egalitarian values. These socialist values that cannot be assumed, or taken for granted, but must be rigorously thought out and then vigorously defended. In the end, socialism is a fundamentally moral endeavour.

\section{The Future of Socialism}

Both separately and together, Bannerji and Cohen suggest that the contemporary capitalist world is, for far too many, intolerable and unjust. This implies the need for radical transformation. At the same time, it is because they use the vantage point of a more just, socialist world, that they are able to denaturalize and morally condemn what appears to be the commonsensical, inevitable and even desirable ways of organizing social life that are typical within capitalism. As Bannerji observes, it is because she writes with a vision of "resistance and revolution" that she is able to locate herself and understand her experiences and those of others: "How would I get out of the dead end of a violent 'now', if I did not know what was possible?" (Bannerji 1995, 10).

Nonetheless, their respective emphases are different. Bannerji is most acute in her critique of the multiple aspect of actually-existing capitalist oppressions, simultaneously encompassing race-gender-class, as well as in her discussions of the sometimes contradictory and partial efforts of dominated actors to overcome these. Cohen offers detailed critiques of the principles said to underlie capitalist market societies, but spends less time analysing how capitalist social relationships actually work in practice. Much more energy is used to convince readers, both sympathetic and not, of the moral value and intellectual coherence of the socialist project, as a particular kind of egalitarian philosophy. Arguably, Bannerji focuses on the problems of capitalism; while Cohen offers detailed reasons to support socialism.

There are dangers associated with a more exclusive emphasis on one or the other aspect of socialist theory. In particular, socialism as critique risks, in some variants, becoming a paralysing overdeterminism, so that the current injustices of capitalism become social practices seemingly destined to be reproduced, even if they no longer appear natural nor morally justifiable. On the other hand, socialism as prescription, if unhinged from an appreciation of the dynamics of actually existing capitalism, risks both the reasonable charge of utopianism and the somewhat different problem of a false universalism that, in fact, reproduces 'commonsense' justifications or naturalizations of historically-specific oppressions. 
At best, socialist theories address both elements, of critique and of prescription, keeping them in creative tension. Thus, Bannerji is careful to emphasize that her critique of capitalism, in its various historically specific incarnations, has implications for socialist practice. In particular, she calls for a historical materialist analysis that does not shy away from the complexity and specifics of oppressions within world capitalism. This means moving away from either/or formulations to more socially-accurate - and therefore more potently mobilizing - theories of social change. In her own words:

there is enough ground in Marx' works to create social movements that need not choose between culture, economy, and society or 'race,' class, and gender to organize politics of social revolution. Going beyond gestures of intersectionality, coalition, and social cohesion, Marxists have recourse to a non-fragmentary understanding of the social that could change the world as we know it (Bannerji 2005, 157).

For those developing Cohen's work, Cohen has already largely refuted the charge of "utopianism" in his strenuous attention to the details and coherence of the socialist project. His "thick" and detailed defence of socialist principles, in itself, makes the socialist project more present and credible.

However, Cohen can be criticized for engaging in a debate with "universal" aspirations with participants who are anything but. The frequency in Cohen's citations of other white, male analytical philosophers -- Elster, Roemer, sociologist E.O.Wright and so on, for the Marxist side, but then also Nozick, Rawls, Narveson and so on, for the opposition -- does suggest there is a problem with Cohen's socialist philosophy. This mirrors contemporary historical materialist debates, which too often reflect this kind of non-arbitrary exclusiveness among participants. Since it is clearly not obvious to nonwhite scholars and activists why Cohen's approach matters - there is no dialogue with such scholars- there is a burden on those following in Cohen's footsteps to consider how links can be made. If it remains a minority, white man's game, socialism has no future. Within academia and philosophy departments, as well as beyond them, there needs to be outreach to explain why socialism, its values of community and egalitarianism, matter for nonwhite men and women in the dominated classes. For such outreach to be meaningful, many socialists need to begin to educate themselves: this means socialists must take seriously the huge literature by black, Indigenous and other "minority" men and women scholars on social injustice and social, if not always socialist, justice.

Cohen does write about the injuries of racism and he talks about the neglected importance of identity to human beings, within traditional Marxism (on this last point see, for instance, Cohen 2000, 341-363). These are promising entries to a bridge for dialogue with socialist scholars, including those in other disciplines, that -- like Bannerji - take race and gender seriously. The aim here is not to blame, but to mobilize and to 
offer analysis, in order to begin to build socialism beyond its current narrow base to create a society-wide socialist movement. Surely a socialist ethos of "community and egalitarianism" requires no less than a concerted effort to broaden the socialist community and have a socialist debate among equals, who are not all of the same minority (white male) background.

We live in times when there supposedly "is no alternative" to capitalism, despite repeated crises and their devastating effects for the dominated classes. In this environment, it is already a meaningful expression of resistance to proclaim, as Bannerji and Cohen do, that there is a possible and desirable alternative: socialism. The challenge ahead is to make the socialist possibility relevant - not to a small minority - but to each and all.

\section{References}

Alvarez, Maria Laura Arce. 2007. “Too Visible: Race, Gender and Resistance in the Construction of a Canadian Identity in the Poetry of Himani Bannerji”. In Miscelánea: A Journal of English and American Studies. 36: 11-23.

Armstrong, Jeannette C. 2001. "Four Decades: An Anthology of Canadian Native Poetry from 1960 to 2000". In Native Poetry in Canada: A Contemporary Anthology, Jeannette C. Armstrong and Lally Grauer, editors, xv-xx. Peterborough: Broadview Press.

Bannerji, Himani. 1995. Thinking Through: Essays on Feminism, Marxism and AntiRacism. Toronto: Women's Press.

Bannerji, Himani. 2000. Dark Side of the Nation: Essays on Multiculturalism, Nationalism and Gender. Toronto: Canadian Scholars' Press.

Bannerji, Himani. 2001. Inventing Subjects: Studies in Hegemony, Patriarchy and Colonialism. London: Wimbledon Publishing Company.

Bannerji, Himani. 2005. "Building From Marx: Reflections on Class and Race." Social Justice. 32 (4):144-160.

Cohen, G.A. 1995. Self-ownership, Freedom and Equality. Cambridge: Cambridge University Press. 
Cohen, G.A. 2000. Karl Marx's Theory of History: A Defence. Expanded edition. Princeton: Princeton University Press.

Cohen, G.A. 2001. If You're An Egalitarian, How Come You're So Rich? Cambridge: Harvard University Press.

Cohen, G.A. 2009. Rescuing Justice and Equality. Cambridge: Harvard University Press.

Cohen, G.A. 2009. Why Not Socialism? Princeton: Princeton University Press.

Fanon, Frantz. 2011. Oeuvres. Paris: La Découverte.

Rosen, Michael. 2010. "Jerry Cohen: An Appreciation." Available at: http://scholar.harvard.edu/michaelrosen/publications/jerry-cohen-appreciation.

Razack, Sherene. 2008. Looking White People in the Eye: Gender, Race and Culture in Courtrooms and Classrooms. Toronto: University of Toronto Press.

Smith, Dorothy E. 2004. Writing the Social: Critique, Theory and Investigations. Toronto: University of Toronto Press. 